\title{
The marketing of pulses: a neglected area
}

\author{
By J. C. Аввотт, $F A O$, Rome
}

Grain legumes or pulses have in most countries received relatively little attention in official development programmes or from agencies concerned with marketing improvement. The primary focus of developing countries governments has been first on assuring sufficient supplies of the basic food of the country to feed rapidly growing populations and secondly on encouraging the production and marketing of crops that have a high value on foreign markets.

Pulses, in the main, do not offer great potential as earners of foreign exchange nor does a scarcity normally provoke civil disturbance. Nevertheless, they provide a major part of the protein intake for large sectors of the world's population. These are, moreover, predominantly people of low cash income with no easily available alternative protein sources. In these circumstances, e.g. in rural Brazil, a breakdown in supplies could indeed be serious (François \& Sizaret, 1981).

The purpose of this paper is first to bring together in a convenient form available information on the production and consumption of pulses. It will then highlight major marketing and related economic issues on the basis of the situation and trends in some of the main developing countries.

\section{Production}

Table I provides values for total production and yields of pulses and cereals for the world as a whole, for Europe and for a few of the major developing countries. This paper focuses on Brazil, Nigeria, India and China in order that the discussion of production and marketing conditions can be specific. China is included as well as India as a representative of a centrally planned economic system. The production values are taken from FAO Production Yearbooks and its definition of pulses is followed throughout the paper. Under pulses are included all grain legumes which are harvested dry. If harvested green for human consumption they are classified as vegetables. Thus, according to the understanding between FAO and national reporting agencies, peas planted by a farmer and sold fresh for freezing and canning would be vegetables. That part of the same crop which did not find a fresh market outlet would be counted as pulses. Groundnuts and soya beans are classified as oilseeds (in the view of some observers, the production values for pulses supplied from China do, in fact, include soya beans consumed as beans, i.e. not processed). This is a policy of long standing, agreed with representatives of European governments. From 1975 the listing of individual pulses was limited in compliance with a request to reduce the amount of paper issued by FAO. All, however, are included in the totals; those values not printed may be obtained on request from the FAO Statistics Division. Revisions occur as governments correct the information they issued previously. 
Table I. Total production and yield of pulses and cereals*

( $1969-71$ and $197^{8-80}$ annual averages)

\begin{tabular}{|c|c|c|c|c|c|c|}
\hline & \multicolumn{2}{|c|}{$\begin{array}{c}\text { Production } \\
\text { (thousand tons) }\end{array}$} & \multirow{2}{*}{$\begin{array}{c}\text { Increase } \\
(\%)\end{array}$} & \multicolumn{2}{|c|}{ Yield (kg/ha) } & \multirow{2}{*}{$\begin{array}{c}\text { Increase } \\
(\%)\end{array}$} \\
\hline & $\overparen{1969-71}$ & $1978-80$ & & $1969-71$ & $197^{8-80}$ & \\
\hline \multicolumn{7}{|c|}{ Pulses } \\
\hline Brazil & 2453 & 2179 & -I I & 634 & 478 & -25 \\
\hline China & I I 024 & I $33^{89}$ & $2 \mathrm{I}$ & 928 & 961 & 4 \\
\hline India & I 365 & I I 292 & $-\mathbf{I}$ & $5^{17}$ & 487 & -6 \\
\hline Nigeria & 849 & 880 & 4 & 214 & 214 & o \\
\hline Europe & 3428 & 2494 & -27 & 772 & 892 & 16 \\
\hline World & 47337 & $4^{8734}$ & 3 & 696 & 680 & -2 \\
\hline \multicolumn{7}{|c|}{ Cereals } \\
\hline Brazil & 22353 & $28 \circ 72$ & 26 & I 334 & 1366 & 2 \\
\hline China & 209800 & 283000 & 35 & 1829 & 2081 & 14 \\
\hline India & II I I 100 & I 37900 & 24 & 1108 & 1331 & 20 \\
\hline Europe & 199100 & 249700 & 25 & 2963 & 3529 & 28 \\
\hline World & 1245000 & I 566000 & 26 & 1772 & 2021 & 16 \\
\hline
\end{tabular}

On a world basis, production of pulses increased by approximately $3 \%$ over the last decade - a decline relative to the increase in population. This decline was pronounced in Brazil-also in India and to a lesser extent Nigeria. In Europe it was very sharp indeed. In Russia as much as 12 million tons were once grown, mostly peas, but current production is half that. In the warmer temperate zones the great competitor in the crop rotation has been the soya bean. Production of soya beans doubled in the USA during the last decade and increased from $\mathrm{I} \cdot 2$ to I 45 million tons in Argentina and Brazil. In this period, agricultural production priority in general has centred on cereals. Compared with a world production increase of $3 \%$ for pulses, that for cereals was $26 \%$. The expansion of cereal output was of the same order in India, where it was vitally needed to provide basic sustenance for a rapidly expanding population, as in Europe, where Common Market politics have brought high prices for basic grains.

Commercial farmers on rain-fed land tend to regard grain legumes as rather difficult to handle and risky. They have experience of poor germination and losses due to shattering at harvest. The yield figures for the developing countries in Table I point the contrast between the great increases achieved with cereals and the static situation of pulses. Much of this reflects advances in crop breeding in the favoured crops. Grain legumes have their role between cereal crops in rebuilding the nitrogen content of the soil. In this, however, they can be replaced by other legume crops and by manufactured fertilizer. Thus they have been driven out of southern Brazil by the soya bean; production of beans for direct human consumption is now essentially by smaller farmers in the drier northern areas. 
Pulses are also grown mainly by small farmers in rather dry areas in India and Nigeria. Indeed, in some parts of India, pulses (e.g. grams) may be inter-cropped with cereals with the expectation that if the cereal crop fails there will still be some return. This may be sound practice for a subsistence agriculture. The financial return needs to be high, however, if this kind of production system is to be maintained in the face of economic development that offers other opportunities of earning a living.

Ratios of legume prices at the farm level to those of the major cereal are shown over recent decades in Table 2. Additionally, though pulses may need some $\mathrm{N}$ fertilizer as a starter, they fix extra $\mathrm{N}$ in the soil for the following crop. Taking 30 to $40 \mathrm{~kg} \mathrm{~N} / \mathrm{ha}$ as the contribution of a cowpea to a succeeding maize crop in Nigeria and $\$ 300 /$ ton as the price of urea, the $\mathrm{N}$ contribution attributable to the cowpeas at current yields could be around $\$ 100 /$ ton.

In China, with a directed agriculture organized on a commune basis, there has been a strong attachment to traditional principles of fertility maintenance. Beans and peas have their rotational role in northern Chinese agriculture and-if the figures are correct-production is being maintained in spite of prices which are relatively low compared to those of cereals.

The evident need on the production side is for varieties offering much higher yields at lower risk. Putting up prices to attract more supplies under existing production conditions could well defeat its purpose since the end market is with low-income consumers.

\section{Protein supply role}

FAO estimates of amounts of the main pulses available for daily consumption in the four illustrative developing countries are shown in Table 3. Table 4 summarizes FAO information on protein and carbohydrate content.

Table 2. Legume prices as percentage of price of major cereal

(Annual average for producer markets)

$\begin{array}{lccc} & 1961-65 & 1970 & \text { Recent } \\ \begin{array}{l}\text { Brazil: } \\ \text { Beans }\end{array} & 287 & 41 \text { I } & 292 \\ \begin{array}{l}\text { China: } \\ \text { Broad beans }\end{array} & 111 & 111 & 111 \\ \quad \begin{array}{l}\text { Peas } \\ \text { India: } \\ \quad \text { Chickpeas }\end{array} & 120 & 120 & 120 \\ \begin{array}{l}\text { Nigeria: } \\ \text { Cowpeas }\end{array} & 90 & 108 & 124 \\ \begin{array}{l}\text { LK: } \\ \text { Peas }\end{array} & 237 & 221 & 386 \\ & 240 & 208 & 175\end{array}$

"Calculated from Government buying prices and FAO estimates. 
Table 3. Average consumption of pulses (1975-77)*

\begin{tabular}{lcccc} 
& \multicolumn{4}{c}{ Consumption (g/head per d) } \\
\cline { 2 - 5 } & Brazil & China & India & Nigeria \\
Beans & 46.7 & 7.9 & $9 \cdot 3$ & - \\
Broad beans & 1.6 & $12 \cdot 2$ & 9.3 & - \\
Peas & 0.3 & 10.7 & $1 \cdot 7$ & - \\
Chickpeas & 0.1 & - & 17.2 & - \\
Pigeon peas & - & - & $7 \cdot 3$ & - \\
Lentils & 0.1 & - & 1.6 & - \\
Cowpeas & - & - & - & $21 \cdot 0$ \\
Others & - & - & - & $1 \cdot 3$ \\
Total & 48.8 & 30.8 & 40.8 & $22 \cdot 3$
\end{tabular}

-Taken from FAO Food balance sheets and per caput food supplies, 1975-77 average, Rome 1980.

Table 4. Carbohydrate and protein content of pulses and rice*

(Values expressed as $\mathrm{g} / \mathrm{l} 00 \mathrm{~g}$ edible portion of dried mature whole seeds)

$\begin{array}{lcc} & \begin{array}{c}\text { Carbohydrate } \\ (\mathrm{g})\end{array} & \begin{array}{c}\text { Protein } \\ (\mathrm{g})\end{array} \\ \text { Bean } & 62 \cdot 7 & 20 \cdot 3 \\ \text { Broad bean } & 56 \cdot 9 & 25 \cdot 0 \\ \text { Pea } & 60 \cdot 1 & 22 \cdot 2 \\ \text { Chickpea } & 60 \cdot 9 & 19 \cdot 4 \\ \text { Pigeon pea } & 63 \cdot 4 & 20 \cdot 4 \\ \text { Lentil } & 65 \cdot 0 & 20 \cdot 2 \\ \text { Cowpea } & 61 \cdot 0 & 22 \cdot 7 \\ \text { Rice, polished } & 80 \cdot 4 & 6 \cdot 4 \\ \text { Taken from FAO Food composition tables for use in East Africa, } 1972 .\end{array}$

Changes in the role of pulses as a source of protein over the last two decades are shown in Tables 5 and 6 . In Brazil 20 years ago, pulses, essentially beans, supplied almost a quarter of the protein in the average diet. This proportion has tended to decline steadily as incomes have risen, with a corresponding shift to animal products. The three other countries with a much higher ratio of population to productive land have about the same total average protein intake. In China protein intake has risen remarkably mainly through increased consumption of cereals, but also with a noteworthy increase in animal products. India has a much lower animal product intake and a declining contribution from pulses, suggesting greater dependence on cereal protein amongst lower income groups. In Nigeria the role of pulses has increased somewhat. Here, in spite of expanded imports of animal products based on oil revenues, total protein consumption has declined, likewise in India, as supplies have had to be spread over a rising population. The values for Europe demonstrate the situation where income is no longer a nutritionally significant constraint on consumer choice. Animal protein intake has risen sharply 
Table 5. Sources of protein intake*

$\begin{array}{lrrr}\text { Brazil: } & & & \\ \text { Total } & 61 \cdot 2 & 62 \cdot 4 & 62 \cdot 3 \\ \text { Animal products } & 19 \cdot 7 & 21 \cdot 1 & 23 \cdot 3 \\ \text { Pulses } & 14 \cdot 0 & 14 \cdot 0 & 11 \cdot 4 \\ \text { China: } & & & \\ \text { Total } & 53 \cdot 8 & 54 \cdot 9 & 62 \cdot 5 \\ \text { Animal products } & 8 \cdot 8 & 9 \cdot 4 & 11 \cdot 4 \\ \text { Pulses } & 6 \cdot 2 & 6 \cdot 4 & 7 \cdot 0 \\ \text { India: } & & & \\ \text { Total } & 50 \cdot 8 & 49 \cdot 2 & 47 \cdot 3 \\ \text { Animal products } & 5 \cdot 1 & 4 \cdot 8 & 4 \cdot 8 \\ \text { Pulses } & 11 \cdot 2 & 9 \cdot 3 & 8 \cdot 0 \\ \text { Nigeria: } & & & \\ \text { Total } & 52 \cdot 1 & 50 \cdot 3 & 51 \cdot 5 \\ \text { Animal products } & 6 \cdot 3 & 7 \cdot 1 & 7 \cdot 8 \\ \text { Pulses } & 4 \cdot 6 & 4 \cdot 5 & 5 \cdot 0 \\ \text { Europe: } & & & \\ \text { Total } & 89 \cdot 9 & 93 \cdot 0 & 96 \cdot 7 \\ \text { Animal products } & 42 \cdot 3 & 49 \cdot 1 & 53 \cdot 7 \\ \text { Pulses } & 2 \cdot 3 & 2 \cdot 2 & 1 \cdot 7\end{array}$

$\overbrace{1961-65}^{\text {Protein intake (g/head per } \mathrm{d})}$

Taken from FAO Food balance sheets and per caput food supplies 1975-77 average, Rome, 1980.

Table 6. Pulses and animal products as percentages of total protein intake*

$\begin{array}{lccr} & 1961-65 & 1969-71 & 1977 \\ \text { Brazil: } & & & \\ \quad \text { Animal products } & 32 & 34 & 37 \\ \quad \text { Pulses } & 23 & 22 & 18 \\ \text { China: } & & & \\ \quad \text { Animal products } & 16 & 17 & 18 \\ \quad \text { Pulses } & 11 & 12 & 11 \\ \text { India: } & & & \\ \quad \text { Animal products } & 10 & 10 & 10 \\ \quad \text { Pulses } & 22 & 19 & 17 \\ \text { Nigeria: } & & & \\ \quad \text { Animal products } & 12 & 14 & 15 \\ \quad \text { Pulses } & 9 & 9 & \\ \text { Europe: } & & & 25 \\ \quad \text { Animal products } & 48 & 23 & 2 \\ \quad \text { Pulses } & 3 & & \end{array}$

-Calculated from results presented in Table 5. 
to exceed over half the total; pulses are of minimal importance. The values reflect two generally recognized trends: (I) where consumer incomes are fairly high or increasing, protein intake shifts to animal products and the role of pulses declines - eventually to that of a variety dish of limited interest, (2) in a country of intense population pressure and low consumer income, pulses are strategic in maintaining total dietary protein levels. Where the latter are declining this seems to be in direct correspondence with declining availability of pulses. This is the case in India. In Nigeria total protein intake and the proportion of pulses are noticeably static.

\section{Consumer preferences}

In general, pulses have always been a poor man's food. Aristophanes has one of his characters say of a nouveau riche 'He does not like lentils any more' (Doughty $\&$ Walker, r 981). Now, as then, consumers move to livestock products when their income permits it. It is only in India and among scattered vegetarian groups elsewhere, that pulses continue to be a major item in middle and upper income consumer diets. In addition to specific vegetarians, Hindu Brahmins traditionally make great use of pulses at wedding and religious feasts.

Some very high rates of consumption were reported; $240 \mathrm{~g} / \mathrm{d}$ for road workers near Delhi, and as much as $700 \mathrm{~g} /$ person per $\mathrm{d}$ in Rwanda and Burundi (Doughty $\&$ Walker, 1981). These high rates generally apply during the harvest season and to families who are themselves the producers. Most of the beans eaten in the rural areas of Brazil-also China---are home grown or received in lieu of wages or by barter (François \& Sizaret, I981). Choice of type or quality of product according to price on the market does not play an important role in such consumption patterns. When consumers must pay for their pulses, consumption tends to rise with income, until the middle level, and then tail off. This is evidenced by a consumpton survey in Rio de Janeiro (François \& Sizaret, 1981).

The main factors leading to declining consumption when income permits access to alternative proteins would seem to be the much greater variety of flavours and textures of food prepared from livestock products, backed up by the prestige associated with these foods. Supporting considerations are; (I) the time involved in soaking pulses before they are cooked, (2) the long time taken to cook some pulse dishes and, as fuel prices rise, the cost of fuel involved.

On the basis of performance over the period $1963-75$, income elasticity of demand is estimated for Brazil at 0.1 , India 0.7 , Nigeria 0.2 . This means, for example, that when average income rises by $10 \%$ in India consumption of pulses is likely to rise by $7 \%$. For North America and the Common Market countries of Europe the comparable coefficients are below zero, i.e. negative.

Recapturing consumers lost because of the disadvantages of pulses purchased in natural dried form, seems to depend on the application of processing and marketing initiatives. Processes are available for making pulses easy and quick to cook, for combining with them spices and other ingredients to add and vary flavour and for presenting them in a range of forms and textures. In India some 10000 
mills are engaged in dehusking various pulses and splitting them into 'dhal'. Cowpeas are decorticated in Nigeria as a family industry. Sale as cakes ready for eating is an important consumption factor. Application of available technologies could enable the mills in India to raise output yields by $5-10 \%$ and may also be relevant in Nigeria where the cost of processing and storage is a deterrent to consumption (Parpia, 1979). Pulses may also be valued for their mucilaginous and other cooking properties. Some $20 \%$ of black gram flour is used to achieve the desired texture in papada which is widely sold in India. Sale of pre-cooked pulses including a lentil 'dhal' needing only ro min of cooking is expanding rapidly.

The end product of such processing should be able to withstand distribution in bulk without special protection. Unfortunately, the trend is toward consumer packaging. Because of the costs involved, including distribution and promotion, the more elaborate processes are likely to develop openings for pulses as variety dishes for the fairly well off rather than help maintain consumption levels amongst the needy.

Projections of consumption demand for pulses and total production in the year 2000 for Brazil, India and Nigeria are shown in Table 7. The difference between the first two columns represents estimates of seed need, animal feed use and waste. The high projection reflects application of an average annual rate of growth in gross domestic production (GDP) of $7 \%$. This is still less than the average actually achieved by developing countries in the years up to 1980 . The lower rate is based on a $5.7 \%$ rate of growth in GDP. Taking the estimates for the lower growth rate these projections of consumption demand would require that total pulse production be increaed in Brazil by $83 \%$, India by $80 \%$ and Nigeria by $85 \%$. These are the broad guides for production planning over the coming decades. If consumption projected for the year 2000 in these countries is achieved, shortages appear likely to occur except perhaps in Brazil. At the lower growth rate, India

Table 7. Total pulse consumption and production (thousands of tonnes) projected to the year 2000*

\begin{tabular}{|c|c|c|c|c|}
\hline & $\begin{array}{l}\text { Consumption } \\
\text { as food }\end{array}$ & Production & $\begin{array}{l}\text { Export-import } \\
\text { balance }\end{array}$ & $\begin{array}{c}\text { Production } \\
1978-80\end{array}$ \\
\hline \multicolumn{5}{|l|}{ Brazil: } \\
\hline $\mathrm{H}$ & $3^{6} 92$ & 4151 & +7 & \multirow{2}{*}{2453} \\
\hline $\mathrm{L}$ & 3657 & 4000 & -100 & \\
\hline \multicolumn{5}{|l|}{ India: } \\
\hline $\mathrm{H}$ & 20600 & 23900 & -8 & \multirow{2}{*}{ I I 292} \\
\hline $\mathrm{L}$ & I 8346 & 20300 & -929 & \\
\hline \multicolumn{5}{|l|}{ Nigeria: } \\
\hline $\mathrm{H}$ & 1225 & 1742 & -98 & \multirow{2}{*}{880} \\
\hline $\mathrm{L}$ & 1190 & 1650 & -138 & \\
\hline
\end{tabular}


would be in deficit to the extent of nearly I million tons. With lower rates of income growth, more of the increased population remains dependent on pulses for much of its protein. At work here is the low income elasticity of demand for pulses presently prevailing in most consumer societies.

\section{Marketing systems}

In most developing countries pulses are assembled, sold wholesale and retailed by a free enterprise marketing system backed to varying degrees by government marketing support services. Most rural assembly markets in India, for example, are now regulated by committees on which producers are represented. In some areas they are being rebuilt with World Bank funds. In economies organized according to Marxist principles such a marketing system is generally replaced by a single state trading agency combining assembly and wholesale distribution functions. Retailing proceeds mainly through municipal cooperative or other retail organizations, with a tolerated private enterprise fringe. Of the four countries selected, Brazil, India and Nigeria belong to the first category; China is a notable exponent of the second.

According to the findings of various independent surveys, the marketing systems for pulses in Brazil, India and Nigeria all function quite well, subject to the infrastructural and technological resource constraints of their environment (Slater, I 969; Smith, I973; Ejiga \& Robinson, I98I). In all these countries the number of enterprises engaged is too many to offer much scope for monopolistic practice. The survey in north-east Brazil (Slater, 1969) made a specific attempt to verify this. Occasional approaches for collusion over prices were reported by $28 \%$ of the traders in the Brazil area studied. Tied sales for credit agreements reduced the bargaining power of $24 \%$ of the producers. In northern Nigeria the total marketing margin taken on cowpeas was 26 to $30 \%$, about the same as for millet and gari, and much less than the 40 to $60 \%$ taken on maize.

However, this does not at all mean that the marketing system was not a deterrent to expanded production. There is much evidence to suggest that it was; (I) the existence of an extended line of small enterprises and successive independent sales transactions enhanced enterprise costs and risks, and blunted the transmission of quality requirement indications back to producers. Vertical integration was a major recommendation for the Brazil situation (Salter, 1969). (2) Transport difficulties were another constraint. Where roads were passable assemblers picked up beans at the farm in north-east Brazil and the marketing channel was shortened correspondingly. But $60 \%$ of the producers surveyed and $25 \%$ of the assemblers lived on roads used only for oxcart transport. Transport conditions in India and Nigeria would be similar or worse. (3) Lack of systematic and reliable market information was a general complaint. Two-thirds of the producers surveyed in Brazil depended for price information on the buyers of the crop, with the obvious opportunity to distort the facts. Few were reached by official or informed mass-media channels. This was the case also in Nigeria. (4) Seasonal price fluctuations exceeded $50 \%$ in Nigeria and averaged $100 \%$ in the 
Recife districts surveyed. The consequent depressant effect on the farmer who sold at the low point just after harvest and negative impact on consumers faced with high retail prices later in the year is very great. Primary responsibility for this lies in the risk and cost of storage and restricted access to credit on the part both of traders and producers at time of harvest.

Holding a crop after harvesting means foregoing access to cash on the part of the farmer and putting in new money on the part of a trader. Interest has to be paid. In addition, there is the prospect of physical loss and deterioration. A survey in fifty markets carried out monthly over 3 years found weight losses due to insect attacks under traditional conditions in Nigeria averaging $4.7 \%$ (G. H. Caswell quoted in Ejiga \& Robinson, 198I). An interview survey in north-east Brazil elicited estimates of storage and handling losses in beans of $10 \%$ in one channel, $16 \%$ in another (Slater, I 969). Scope for loss reduction through better storage was evident.

In Figs. I and 2 Ejiga \& Robinson (I98I) show monthly coverage wholesale prices for cowpeas at Jos in the centre of Nigeria and Lafia its main supply market. Prices at harvest time plus calculated costs of storage (fixed and inventory capital allowed $5 \%$ /annum) are shown alongside. For the first months there seems to be no return for storage, then it jumps sharply. Returns for moving produce over the I 50 miles of road from Lafia to Jos also go up sharply later in the crop year.

Measures that could be taken to reduce such marketing constraints are; ( $\mathrm{r}$ ) promotion of vertical integration along the marketing processing channel. A

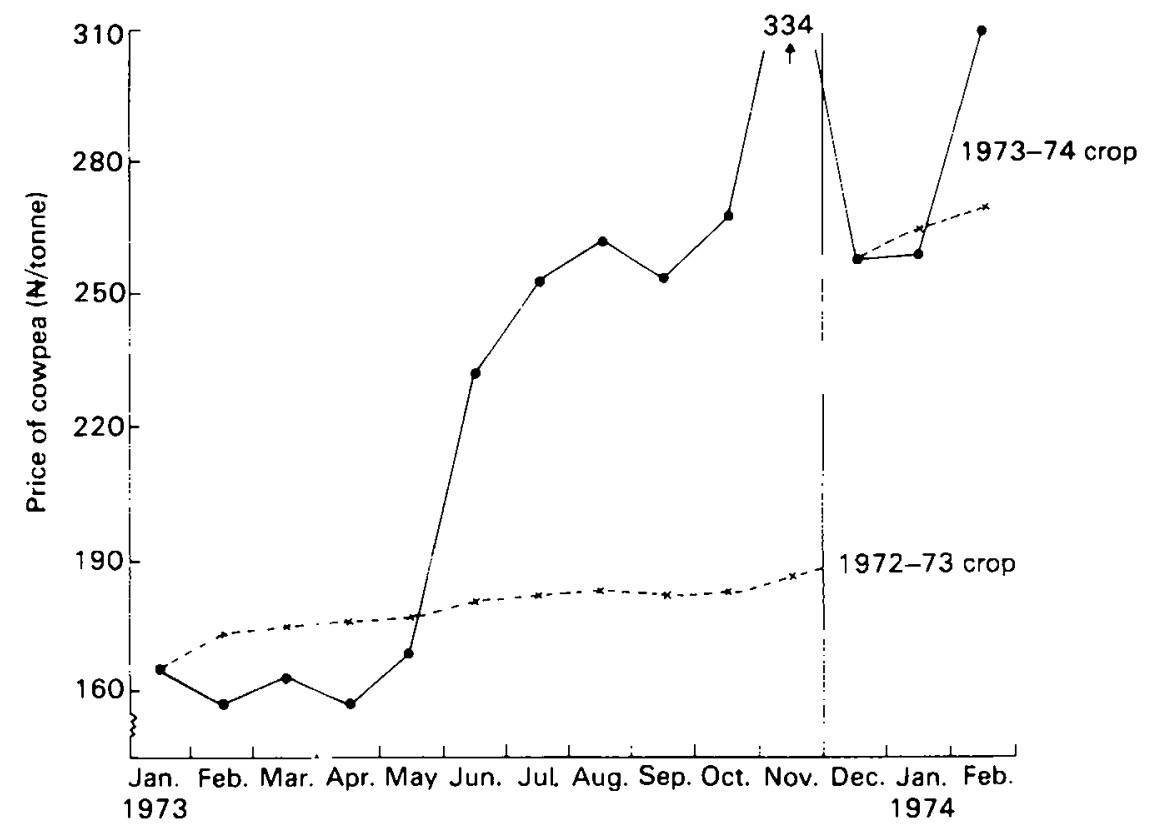

Fig. $\mathrm{r}$. Variations in the wholesale price of cowpea in Jos, a town in the centre of Nigeria. $(x---x)$ Hypothetical price at harvest plus storage cost, -) actual market price (Ejiga \& Robinson, $198 \mathrm{r}$ ). 


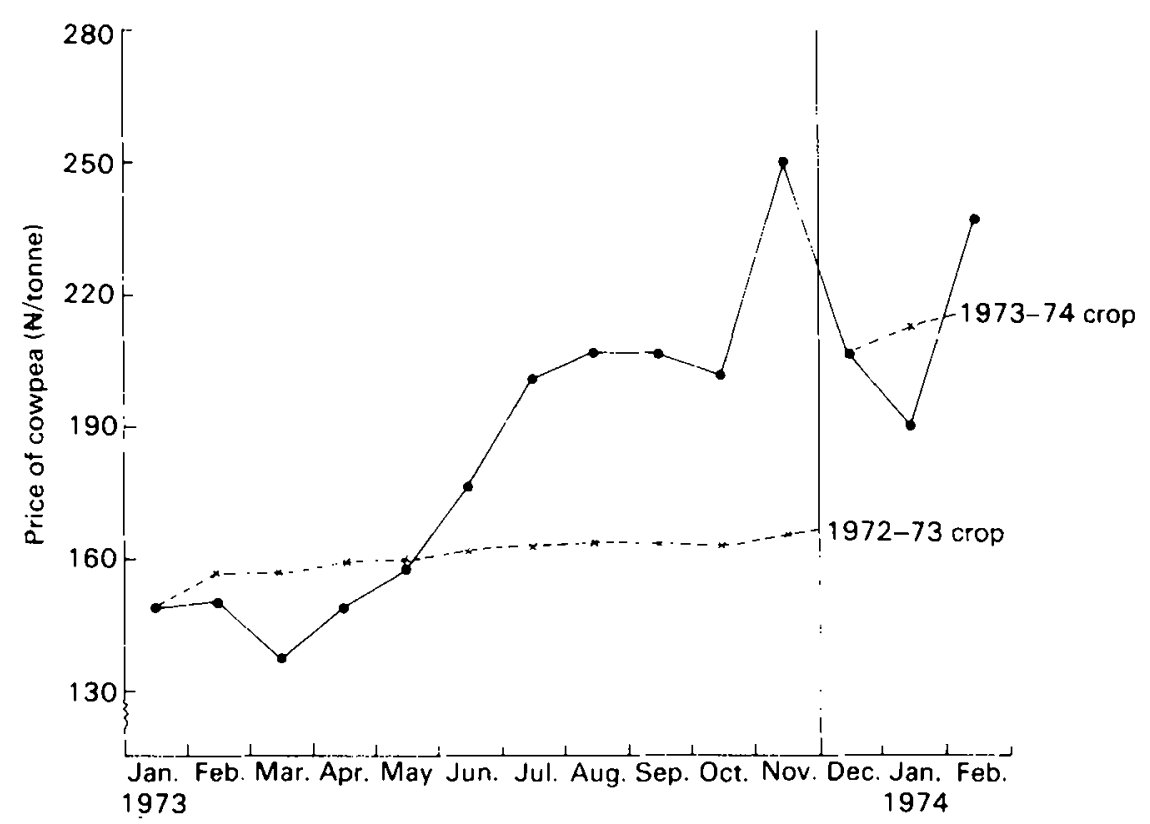

Fig. 2. Variations in the wholesale price of cowpea in Lafia, a main supply market. $(x---x)$ Hypothetical price at harvest plus storage cost, (--O) actual market price (Ejiga \& Robinson, 1981 ).

retailing organization in Recife that set up its own rice mill and purchasing network in the producing area was able to cut its retail price by $15 \%$. (2) Improvement of access roads. Often this can be done by mobilization of local labour during slack seasons of agriculture if central or local authority can build the culverts. (3) Informal information channels can be supplemented by information telephoned to production areas and displayed on notice boards, and by radio programmes beamed to rural audiences. (4) Materials for reducing physical losses in storage can be made available locally and procedures demonstrated. For this to be effective in practice, however, the market must provide a clear price incentive. (5) Tendencies towards excessive seasonal fluctuation in price can be tackled indirectly by provision of better crop supply-and-demand information and easing credit shortages. A more direct approach is to introduce a minimum price guarantee programme implemented by purchases for and sales from a national bufferstock. This was initiated for gram in India in $1976-77$ and later extended. The organizations responsible for implementing these prices are the National Federation of Agricultural Cooperatives in India and the Production Financing Commission in Brazil. The announcement of a minimum price was said to have helped raise output in India in 1978 and 1979. However, in the absence of a purchasing network reaching down to the small farmers, the impact of such price announcements remains for many of them only indirect. 
In China pulses are purchased along with grain by the Food Grain Management Unit, a specialized state agency. There is a fixed price for a specified quota with a premium for quantities supplied in addition. This holds good for the whole season putting the storage responsibility clearly into the hands of the purchasing agency. Losses due to insect infestation, etc. are reportedly low. So marketing risks are greatly reduced. The issue for those making production decisions is then whether the fixed price (plus premium) provides sufficient incentive. By western standards it would seem that the ratio of pulse prices to those of the major cereal is low.

\section{Observations for discussion}

Breeding improved varieties of grain legumes and developing associated production practices can help in a number of ways; ( 1 ) yields may be increased making production much more economic. In Nigeria cowpea harvests average $214 \mathrm{~kg} / \mathrm{ha}$; yields of $3000 \mathrm{~kg} / \mathrm{ha}$ have been achieved at the International Institute of Tropical Agriculture, Ibadan, and of $2200 \mathrm{~kg} / \mathrm{ha}$ in Uganda. (2) Tendencies to shatter early could be bred out so reducing harvesting losses. (3) A more tender outer coat could be developed in some pulses so increasing palatability and reducing the time needed for preparation and cooking.

Development of inoculation by effective rhizobium strains could increase substantially the residual $\mathrm{N}$ available for subsequent crops. This could be increasingly significant as the real costs of energy and transport are reflected back to farmers. In the meantime easier availability of credit and insurance protection against crop failure would reduce risk aversion resistance to the use of high input seed-fertilizer combinations in dry areas and losses during farm handling and storage could be countered by the building of improved structures and systematic infestation controls. Developments in processing cạn help in two complementary directions; ( 1 ) preparation and promotion of spicy, quick cooking, ready prepared pulse dishes would appeal to younger age groups at medium income levels; they would restore lost prestige to grain legume products. (2) Pre-cooking and associated treatments could counter the cooking time and fuel cost constraints on lower income consumers who purchase on the market.

Improvements in marketing infrastructure, organization, procedure and support services could raise prices to producers without prejudice to the interests of consumers. They could facilitate access to improved seed, fertilizers and other supplies providing them on credit and at concessional prices, to better storage and more secure outlets. They could level out seasonal fluctuations to the advantage of both parties and so stimulate both production and consumption.

\section{REFERENCES}

Doughty, J. \& Walker, A. (1981). Legumes in Human Nutrition, and ed. Rome: FAO.

Ejiga, N. O. O. \& Robinson, K. L. (1981). The Economics of Cowpea Marketing in Nigeria, Ithaca, New York: Dept. of Agricultural Economics, Cornell University.

François, P. \& Sizaret, F. (1981). F.A.O. Fd Nutr. 7 (1). 
Parpia, H. A. B. (1979). In Prospettive delle Proteaginose in Italia. Atti del Convegno di Perugia 30 May-2 June 1979.

Slater, C. C. (1969). Market processes in the Recife area of northeast Brazil. Michigan State University: Latin American Studies Center.

Smith, G. W. (1973). Fd Res. Inst. Stud. Stanford 12 (3). 